\title{
LIVER EXTRACT, LIVER ASH AND IRON IN THE TREAT- MENT OF ANEMIA
}

\author{
By CHESTER S. KEEFER, K. K. HUANG AND C. S. YANG
}

(From the Department of Medicine, Peiping (Peking) Union Medical College, Peiping)

(Received for publication June 6, 1930)

\section{INTRODUCTION}

Inasmuch as it has been demonstrated that liver and iron are potent in increasing the hemoglobin output of some patients with anemia, it seemed highly desirable to determine the effect of liver extract, liver ash, and iron in similar cases. Accordingly, we studied the response of the blood of fifty-five patients with anemia using these substances. Fourteen patients were studied following liver extract, ten following liver ash, and thirty-one following various doses of iron. In this paper we present the results of our investigations.

\section{LITERATURE}

Before proceeding it is necessary to review the information which exists regarding the value of liver extract (Number 343 Lilly) and liver ash in the treatment of the various anemias.

Besides increasing the hemoglobin and erythrocyte content of the blood in pernicious anemia (1), liver extract has been found to be effective in the treatment of the anemia of sprue (2) (3) (4) (5), tapeworm anemia (6), in some of the nutritional anemias of childhood (7) (8), in the anemia associated with intestinal strictures (9), chronic dysentery, and pregnancy (10) (11) (12) (13). When it has been given to patients with other forms of anemia the results have varied. For example, Minot, Murphy, and Stetson (13) state that one group of eleven patients showed no response to liver extract which was potent in pernicious anemia, whereas, in another group of ten patients, eight showed a slight increase in the reticulocytes, but they were not over 3.7 per cent. In the remaining two, the reticulocytes increased to from 6 to 8 per cent. From these observations they concluded that liver extract was not effective in most cases of "secondary anemia." However, they stated that if iron were added to liver extract the results were more noticeable than when either was given alone. Vaughn (14) also has reported favorable results in some forms of anemia following liver extract. 
In the experimental anemias of dogs due to bleeding, liver extract has only approximately 10 to 20 per cent of the potency of whole liver, but when liver and liver extract are given together the hemoglobin and erythrocyte production may increase in excess of the sum of the expected separate reactions, whereas liver ash and liver extract show the sum of the two expected reactions (15). In the nutritional anemia of rats which follows a whole milk diet supplemented with iron, liver extract was potent in curing the anemia (16).

The inorganic ash of liver increases blood regenerations in the nutritional anemia of rats (16) and is about one-half as potent as whole cooked liver when fed to dogs with posthemorrhagic anemia (17). When it is given to patients with pernicious anemia, some of the preliminary phenomena of a remission, such as an increase in the reticulocytes may result, but a true remission does not occur until liver extract (Number 343) is given (18). Furthermore, it has been shown that both copper and iron salts which are found in liver ash, increase the hemoglobin output in dogs, and iron is more potent than copper (19) (20).

\section{METHODS OF STUDY}

The methods used were similar to those previously reported by us (21). All of the patients were resident in the Peiping Union Medical College Hospital during the observations. The erythrocytes, hemoglobin, and reticulocytes were determined in the usual manner. The hemoglobin of Sahli was used and checked with the oxygen capacity method so that 100 per cent was equal to 17 grams of hemoglobin or 22.7 volumes per cent oxygen. When liver extract was given, the product manufactured by Parke-Davis and Company was used. Iron was given in the form of ferrous carbonate in amounts varying from 90 to $480 \mathrm{mgm}$. of iron a day. Liver ash was exhibited in amounts which were equivalent to 300 grams of whole liver. The iron content of the liver ash used in these studies was $1.4 \mathrm{mgm}$. per gram of ash.

Results of the treatment of patients with liver extract. In studying the effect of liver extract on the course of various anemias, we selected patients with the types of anemia which, in our experience, usually responded to whole liver feeding. We adopted this procedure in order to determine whether liver extract was beneficial in such cases, and we felt that there was nothing to be gained by studying effects of liver extract in anemias which did not respond to whole liver. This group included anemias of childhood associated with nutritional disturbances, anemias of pregnancy, hookworm infestation, anemias associated with chronic dysentery, and posthemorrhagic anemia. In some cases liver extract was given alone. It usually was given for two weeks or longer, and in those who received iron, it was added after 
the maximum effect had been obtained from liver extract. That is to say, iron was added after the hemoglobin had increased on liver extract and remained at a stationary level for several days. The hemoglobin and erythrocyte values recorded in the table represent the values of the hemoglobin before and after liver extract treatment, and not the number of red cells and amount of hemoglobin after complete recovery. The results are summarized in table 1 . The erythrocytes varied from 600,000 to $4,000,000$ per cubic millimeter,

TABLE 1

Results of treatment with liver extract

\begin{tabular}{|c|c|c|c|c|c|c|c|}
\hline \multirow[b]{2}{*}{ Case } & \multirow[b]{2}{*}{ Type of anemia } & \multicolumn{2}{|c|}{ Red blood cells } & \multicolumn{2}{|c|}{ Hemoglobin } & \multicolumn{2}{|c|}{ Reticulocytes } \\
\hline & & $\begin{array}{l}\text { Before } \\
\text { treatment }\end{array}$ & $\begin{array}{c}\text { After } \\
\text { treatment }\end{array}$ & $\begin{array}{l}\text { Before } \\
\text { treatment } \\
\text { with liver } \\
\text { extract }\end{array}$ & $\begin{array}{l}\text { After } \\
\text { treatment } \\
\text { with liver } \\
\text { extract }\end{array}$ & $\begin{array}{c}\text { Before } \\
\text { treatment }\end{array}$ & $\underset{\text { treatment }}{\text { After }}$ \\
\hline & & $\begin{array}{l}\text { millions } \\
\text { per cu. mm }\end{array}$ & $\begin{array}{l}\text { millions } \\
\text { per cu. mm. }\end{array}$ & per cent & per cent & per cent & per cent \\
\hline 1 & Childhood & 0.80 & 3.50 & 18 & 60 & $\mathbf{0}$ & 35 \\
\hline 2 & Dysentery & 0.60 & 2.50 & 18 & 55 & 1.2 & 38 \\
\hline 3 & Dysentery & 1.00 & 1.60 & 15 & 20 & 0 & 5 \\
\hline 4 & Childhood & 3.00 & 5.25 & 50 & 75 & $\mathbf{0}$ & 6 \\
\hline 5 & Hookworm & 3.50 & 4.50 & 45 & 70 & 4 & 10 \\
\hline 6 & Pregnancy & 2.00 & 3.50 & 45 & 62 & 2 & 11 \\
\hline 7 & Dysentery & 4.00 & 4.50 & 40 & 50 & $\mathbf{0}$ & 3 \\
\hline 8 & Dysentery & 2.25 & 2.75 & 55 & 65 & 1 & 7 \\
\hline 9 & Dysentery & 2.75 & 3.50 & 40 & 50 & $\mathbf{0}$ & 4 \\
\hline 10 & Dysentery & 3.05 & 4.90 & 52 & 100 & 1.6 & 6.4 \\
\hline 11 & Dysentery & 1.35 & 1.25 & 35 & 40 & 0 & 1 \\
\hline 12 & Dysentery & 1.15 & 1.50 & 14 & 20 & 0 & 3 \\
\hline 13 & Posthemorrhagic & 1.75 & 2.20 & 32 & 35 & 2 & 5 \\
\hline 14 & $\begin{array}{l}\text { Tuberculosis of } \\
\text { intestine }\end{array}$ & 2.00 & 2.00 & 45 & 40 & 4 & 10 \\
\hline
\end{tabular}

and the hemoglobin from 18 to 55 per cent. In ten of the fourteen patients studied there was a definite acceleration of the hemoglobin regeneration. In some it was considerable, while in the others it was not very striking. In the remaining patients, there were no signs of improvement. In some of those showing improvement the effect of liver extract was enhanced by iron. Chart 1 shows the results of liver extract in Case 1.

Chart 2, Case 2, shows the response of the blood following liver extract in a patient with anemia associated with chronic dysentery. 


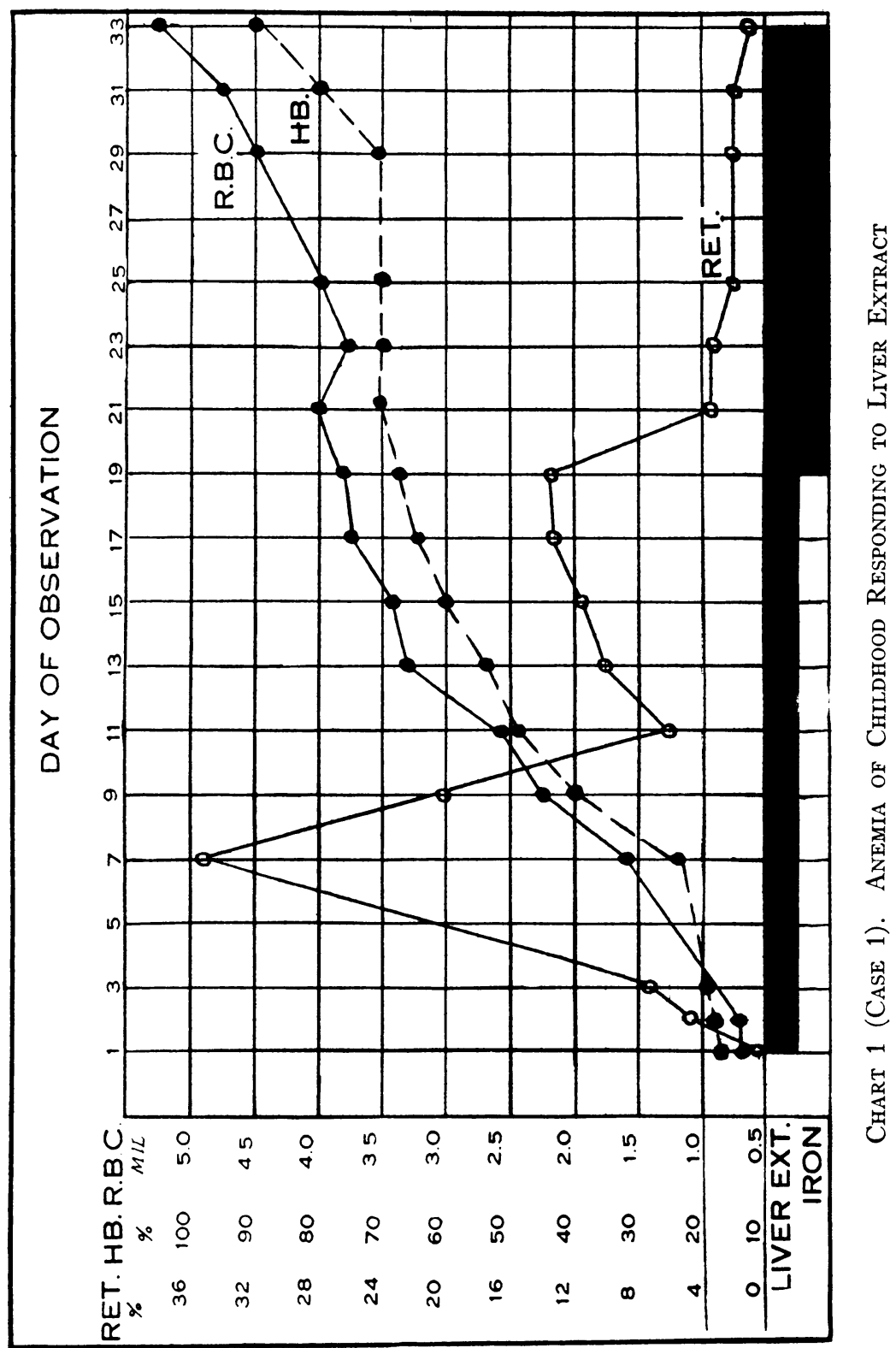




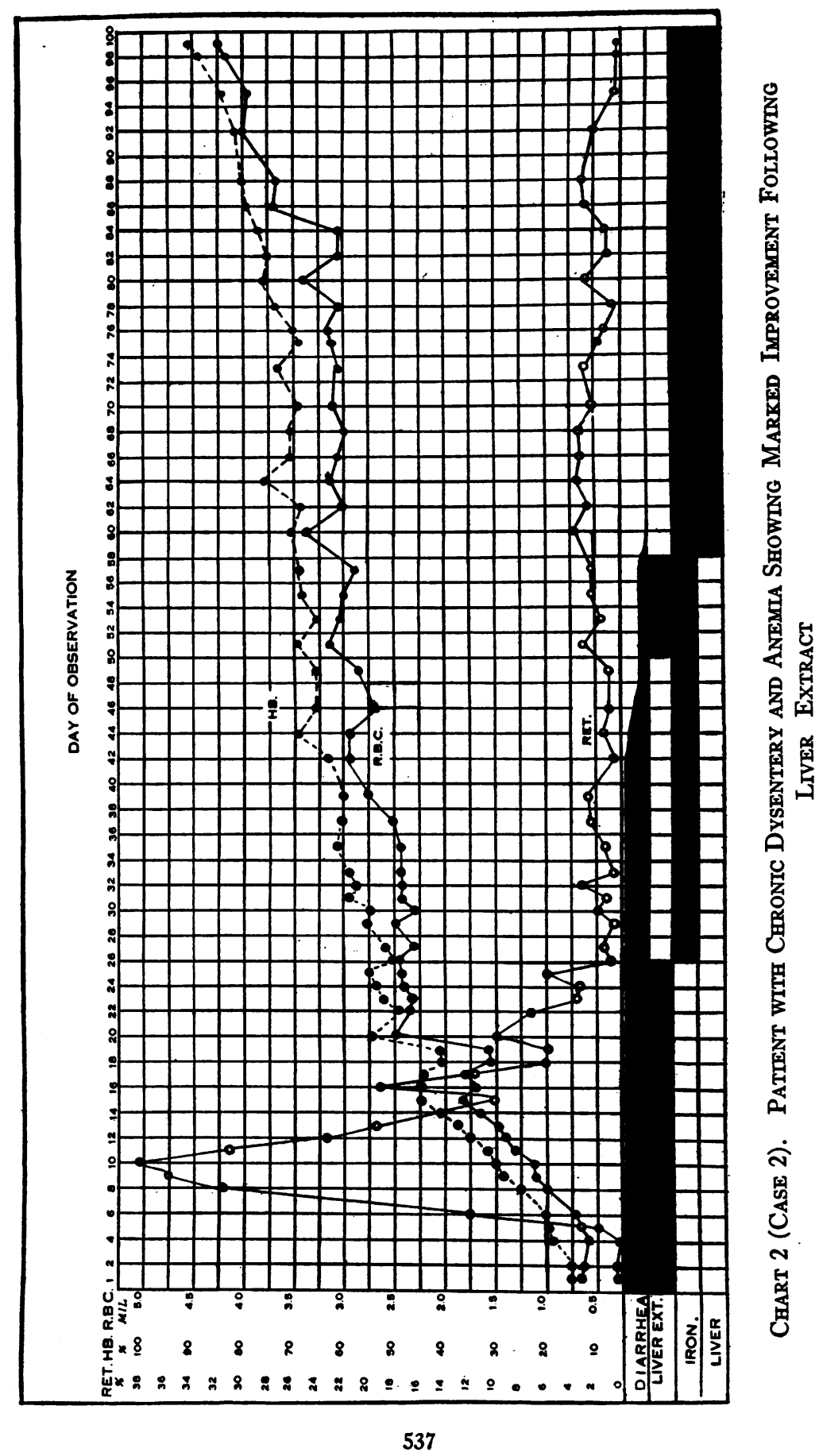


Chart 3, Case 3, illustrates the response of the blood following iron after liver extract failed to produce improvement.

In the patients who responded favorably to liver extract there was an increase in number of reticulocytes in the peripheral blood, the number at the peak of the rise depending upon the level of erythrocytes before treatment was begun.

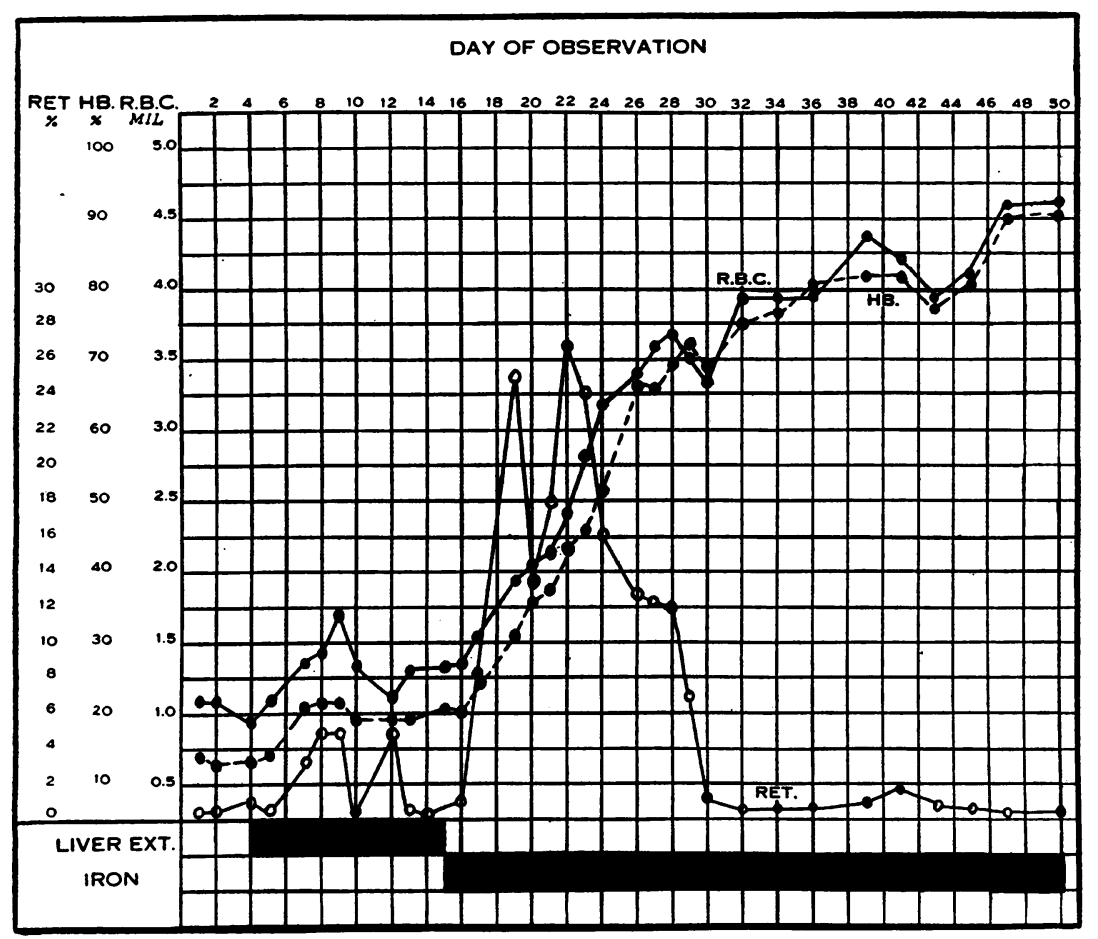

Chart 3 (Case 3). Patient with Anemia Associated with Chronic Dysentery Showing no IMprovement Following Liver Extract bUt a Prompt RECOVERY Following IRON

The value of liver ash in the treatment of anemia when compared with iron. In a previous paper we (21) pointed out that iron was of value in the treatment of some forms of anemia and the daily rate of hemoglobin regeneration following iron in the cases reported varied between 0.5 and 2.2 per cent a day. It was also noticeable that the effect of liver was enhanced by iron feeding. As a result, we proceeded to 
determine whether the response to liver was due to its inorganic constituents, of which iron is one, or to other substances. We studied the course of the blood in patients with anemia and the value of liver ash as compared with iron and liver. The liver ash was prepared by mincing the liver in a meat grinder and drying it in an oven until a fine brown powder was obtained. It was then burned with a hot flame until a carboniferous mass was formed. This was then ground in a mortar and heated again until a fine gray powder was obtained. The results of liver ash feeding are summarized in table 2 . The values recorded correspond to those at the beginning and end of treatment.

TABLE 2

Results of the treatment of anemia with liver ash

\begin{tabular}{|c|c|c|c|c|c|c|c|}
\hline \multirow{2}{*}{ Case } & \multicolumn{2}{|c|}{ Red blood cells } & \multicolumn{2}{|c|}{ Hemoglobin } & \multicolumn{2}{|c|}{ Reticulocytes } & \multirow{2}{*}{ Type of anemia } \\
\hline & $\begin{array}{c}\text { Before } \\
\text { liver ash }\end{array}$ & $\underset{\text { liver ash }}{\text { After }}$ & $\begin{array}{l}\text { Before } \\
\text { liver ash }\end{array}$ & $\begin{array}{c}\text { After } \\
\text { liver ash }\end{array}$ & $\underset{\text { treatment }}{\text { Before }}$ & $\begin{array}{c}\text { After } \\
\text { treatment }\end{array}$ & \\
\hline & millions & millions & per cent & per cent & per cent & per cent & \\
\hline 15 & 3.75 & 4.0 & 42 & 50 & 0 & 4.8 & Dysentery \\
\hline 16 & 3.50 & 4.0 & 40 & 45 & 0.4 & 1.8 & Nutritional \\
\hline 17 & 3.00 & 4.25 & 52 & 65 & 0 & 4 & Edema disease \\
\hline 18 & 2.11 & 2.44 & 37 & 38 & 0.1 & 1.2 & Hookworm \\
\hline 19 & 4.00 & 4.0 & 70 & 75 & 4 & 0 & Edema disease \\
\hline 20 & 2.57 & 2.50 & 34 & 33 & 1 & 1.0 & Posthemorrhagic \\
\hline 21 & 2.02 & 1.92 & 43 & 35 & 0.4 & 3 & Cirrhosis of liver \\
\hline 22 & 3.46 & 4.41 & 43 & 55 & 0.8 & 3.4 & Posthemorrhagic \\
\hline 23 & 3.33 & 3.28 & 53 & 47 & 1.6 & 2.6 & Dysentery \\
\hline 24 & 2.86 & 2.72 & 65 & 58 & 2.6 & 4.8 & Dysentery \\
\hline
\end{tabular}

In several there was a slight increase of the erythrocytes, hemoglobin, and reticulocytes, but complete recovery was never observed.

Following the observations of liver ash, liver or iron was given and the results compared. In most instances, the changes were striking and may be illustrated clearly by means of charts.

Charts 4 and 5 illustrate the course of the blood of two patients with a chlorotic type of anemia associated with malnutrition. In one (chart 4, Case 15) no improvement followed liver ash. When the equivalent amount of whole liver was given daily for fourteen days, there was slight improvement with an increase of the various elements of the blood; but following large doses of iron, recovery occurred 


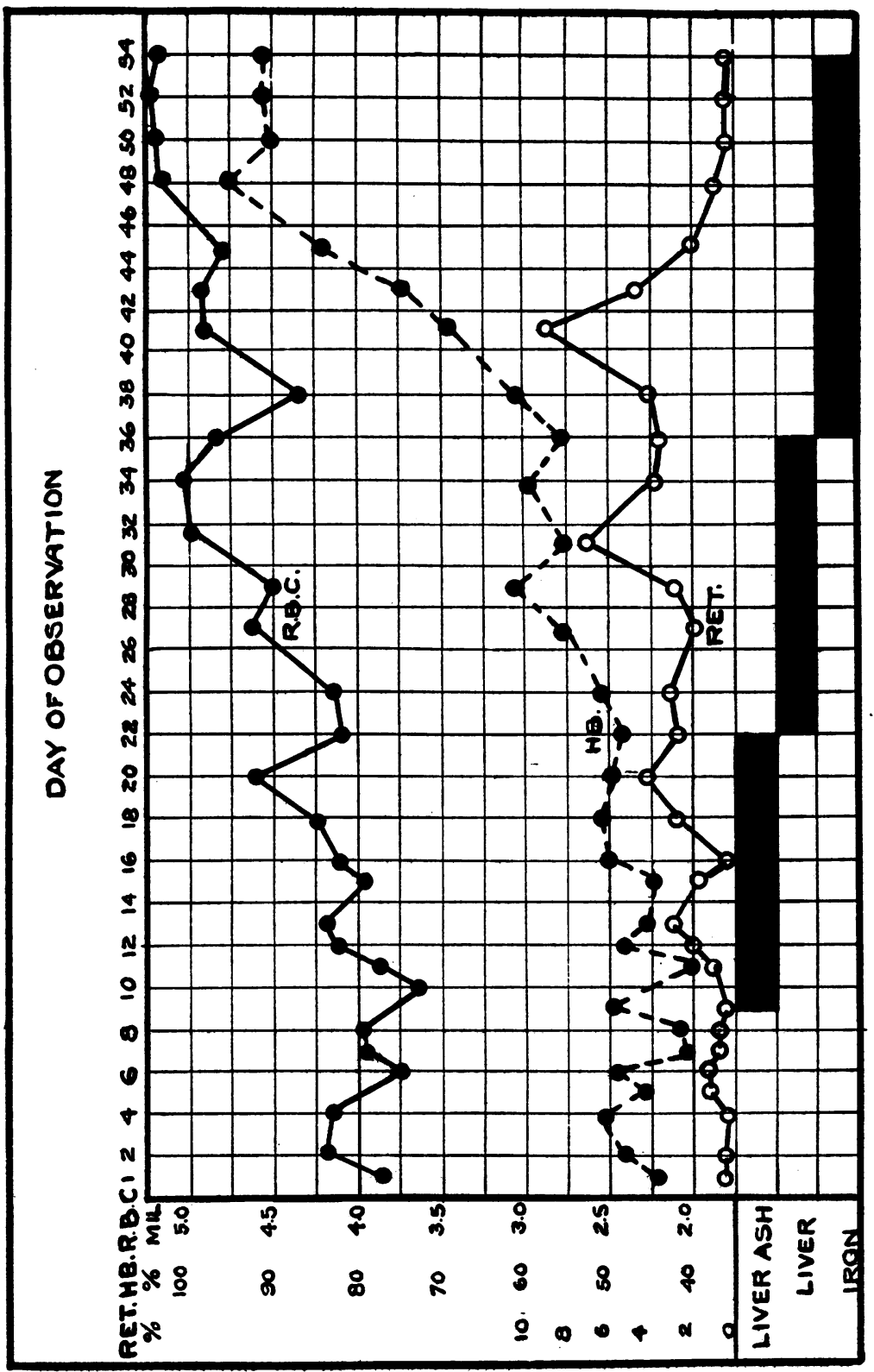

荳

롤

잉

奥

花

य눙 준

$\forall$ 田

业 4

齐

충

急

的

영

国

田

然

淟出京

คิำ

娄䒺

舟合

篦

고 곰

国邽

4

$\varangle$

중

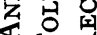

舟

思藏里

空品

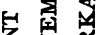

定

要

罗罗

的号占

身家

已

+ 焉

苞 

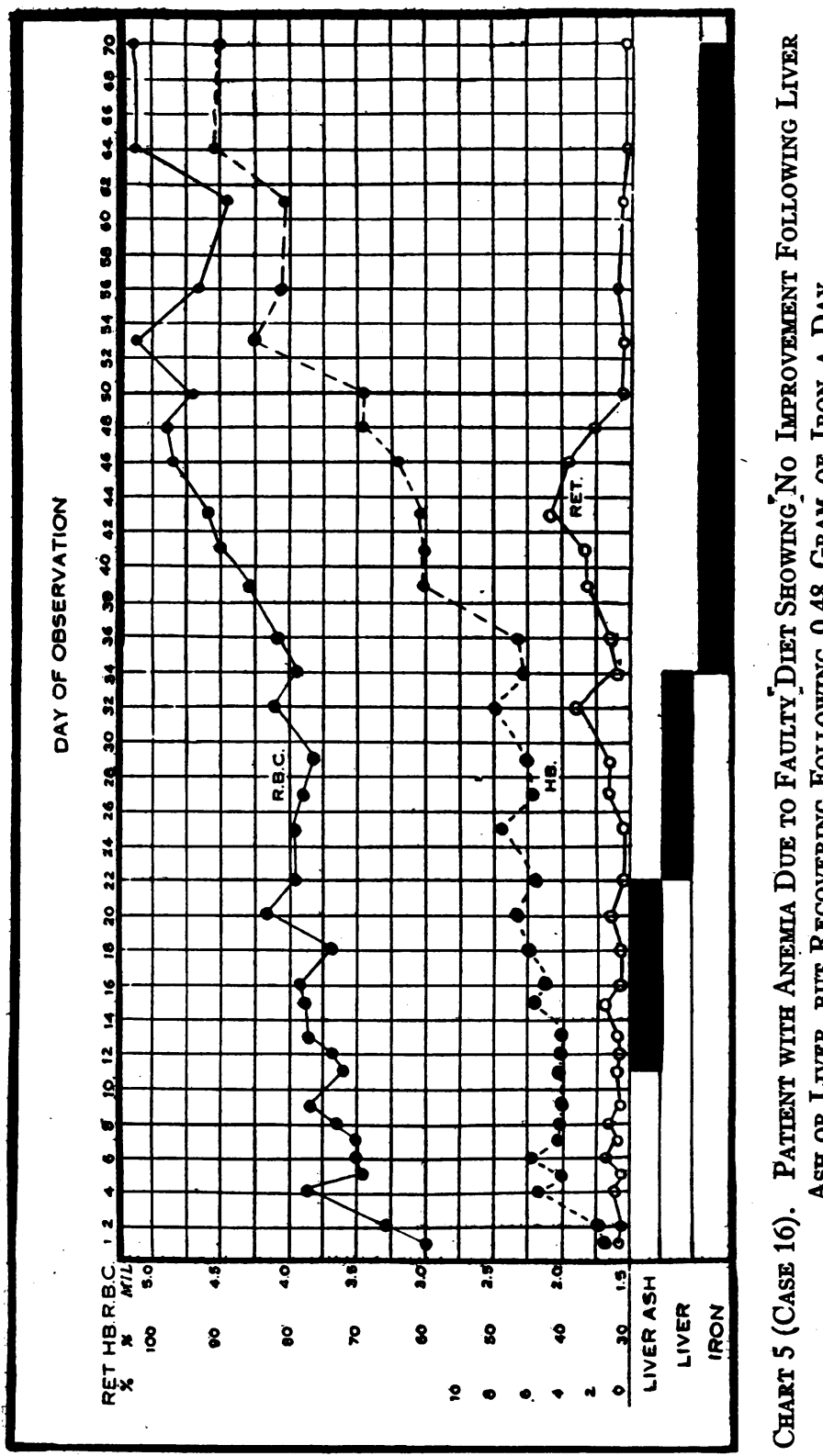
promptly. In the other patient (chart 5, Case 16) no demonstrable improvement resulted from liver ash or whole liver, whereas complete recovery followed iron. These two cases illustrate that the inorganic elements of liver were of little value in these patients when given in amounts equivalent to 300 grams of whole liver, whereas large doses of iron were effective.

Charts 6 and 7 illustrate the difference between the reactions of liver ash and iron. In Case 17 (chart 6) there was temporary improvement of the anemia following hospital diet and the subsidence of the symptoms of dysentery. This was followed by an exacerbation of the dysentery and a fall in hemoglobin and red blood cell count. Following liver ash there was an increase of red cells, and a slight increase in the hemoglobin content of the blood. However, the hemoglobin did not return to normal until after the administration of iron.

In Case 18 (chart 7) the anemia was associated with hookworm infestation. There was no response to liver ash, but marked improvement following iron. Whole liver caused no further improvement.

In Case 19 (chart 8) the anemia was associated with undernutrition and edema disease. There was a satisfactory response to iron which was not enhanced by liver ash.

From the above cases it is clear that liver ash was of little demonstrable value when given in amounts which were equivalent to 300 grams of whole liver a day. In some a similar amount of whole cooked liver was more effective than liver ash. However, when these results were compared with iron, the contrast was striking and requires further comment.

On the basis that iron is one of the potent factors of liver ash, it is surprising that we did not observe more conspicuous results following its exhibition and more particularly since the response in the same patients was so remarkable following large doses of iron.

In attempting to explain why this should be so, it is necessary to keep in mind the available facts regarding the production of hemoglobin following iron feeding in animals. The question continues to be a controversial one. In the experience of different investigators, the results of iron feeding have not been in agreement. These differences are, no doubt, due to the fact that iron has been tested in the various anemias of rats, and the results compared with those following 

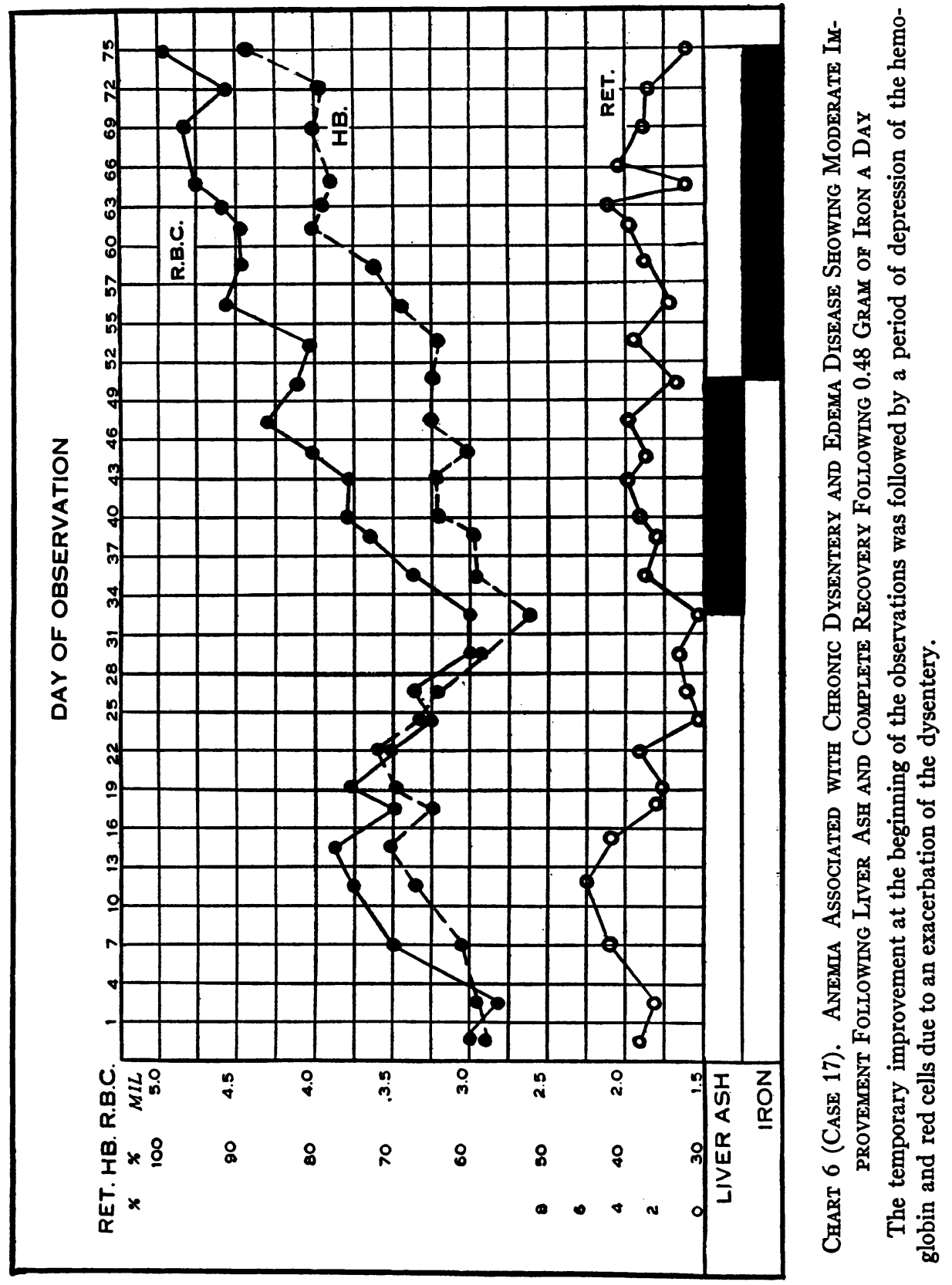


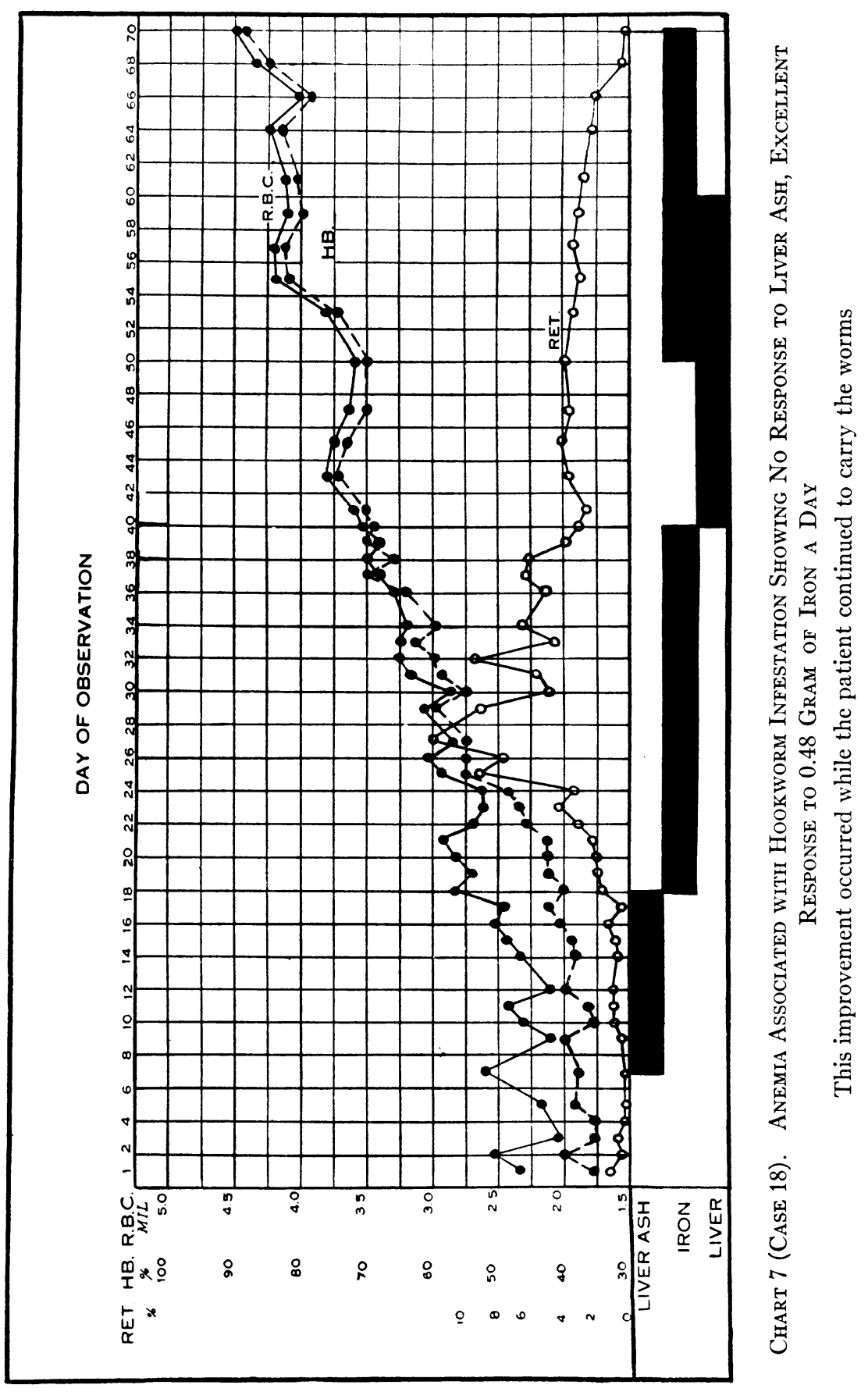


CHESTER S. KEEFER, K. K. HUANG AND C. S. YANG

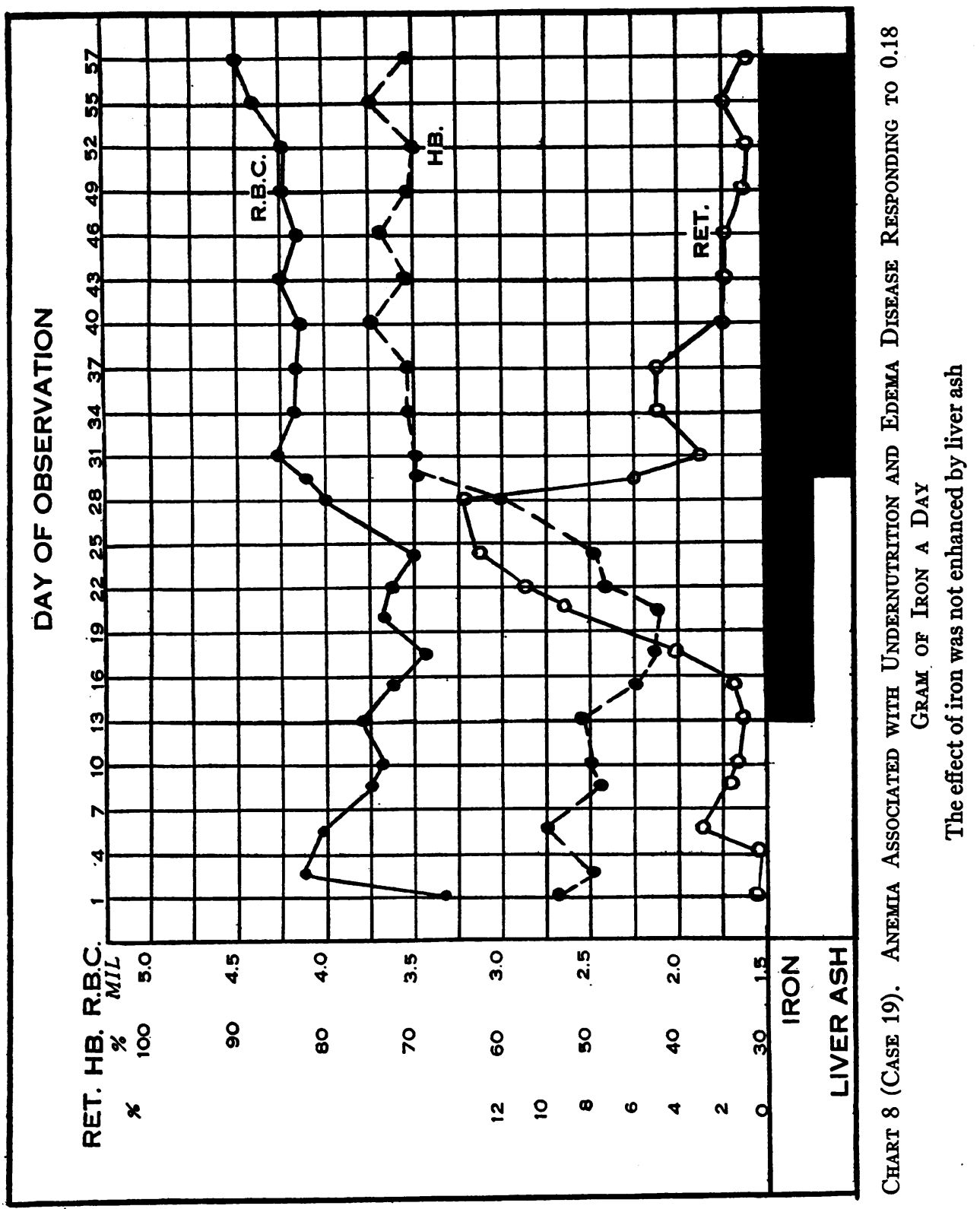


iron feeding in other animals with anemias of different cause. Since there are several factors involved in hemoglobin production, and the iron effect is only one, it is not surprising that the results have varied. This question was reviewed recently by Robscheit-Robbins (22). She emphasized these differences quite clearly and concluded from her own observations on dogs with anemia due to bleeding, that large doses of iron were more effective than small ones. Whipple and RobscheitRobbins (23) found that the maximum effect could be obtained following $40 \mathrm{mgm}$. of iron a day. When more iron was given the output of hemoglobin was not increased, and since this amount of iron was always in excess of that which was contained in the hemoglobin produced, it was concluded that the action of iron was catalytic in nature and caused a readjustment of the internal protein metabolism so that more hemoglobin was produced.

It is evident from these studies that the dosage of iron is of considerable importance in promoting hemoglobin regeneration, whereas the exact mechanism by which it produces its effect is not quite clear.

In considering the part played by iron in the production of hemoglobin in man, it will be acknowledged generally that it is of value in the treatment of some forms of anemia. It has been emphasized by Mettier and Minot (24) that large doses of iron are necessary in order to obtain the maximum effect. To gather further information regarding this question we have made observations in thirty-eight patients who received various amounts of iron daily.

The iron was given in the form of ferrous carbonate, so that the amount of iron varied between 90 and $480 \mathrm{mgm}$. daily. The results are plotted in chart 9. Each dot represents a patient, and the position of the dot on the chart illustrates the rate of hemoglobin regeneration following the dose of iron exhibited. The two squares and two triangles represent the rate of hemoglobin regeneration in two patients following different doses of iron. In these patients, the large dose of iron increased the hemoglobin regeneration more than the smaller one. However, from the chart it is clear that in some cases at least, a positive effect was produced by as little as $90 \mathrm{mgm}$. of iron a day. When one compares the hemoglobin regeneration following $21 \mathrm{mgm}$. of iron daily, when given in the form of liver ash, with that following larger amounts of iron, the results are striking. The dots in the lower 
left-hand corner of the chart represent the hemoglobin regeneration following liver ash. Following these doses the hemoglobin output was slight, whereas, following larger doses of iron the increase was consider-

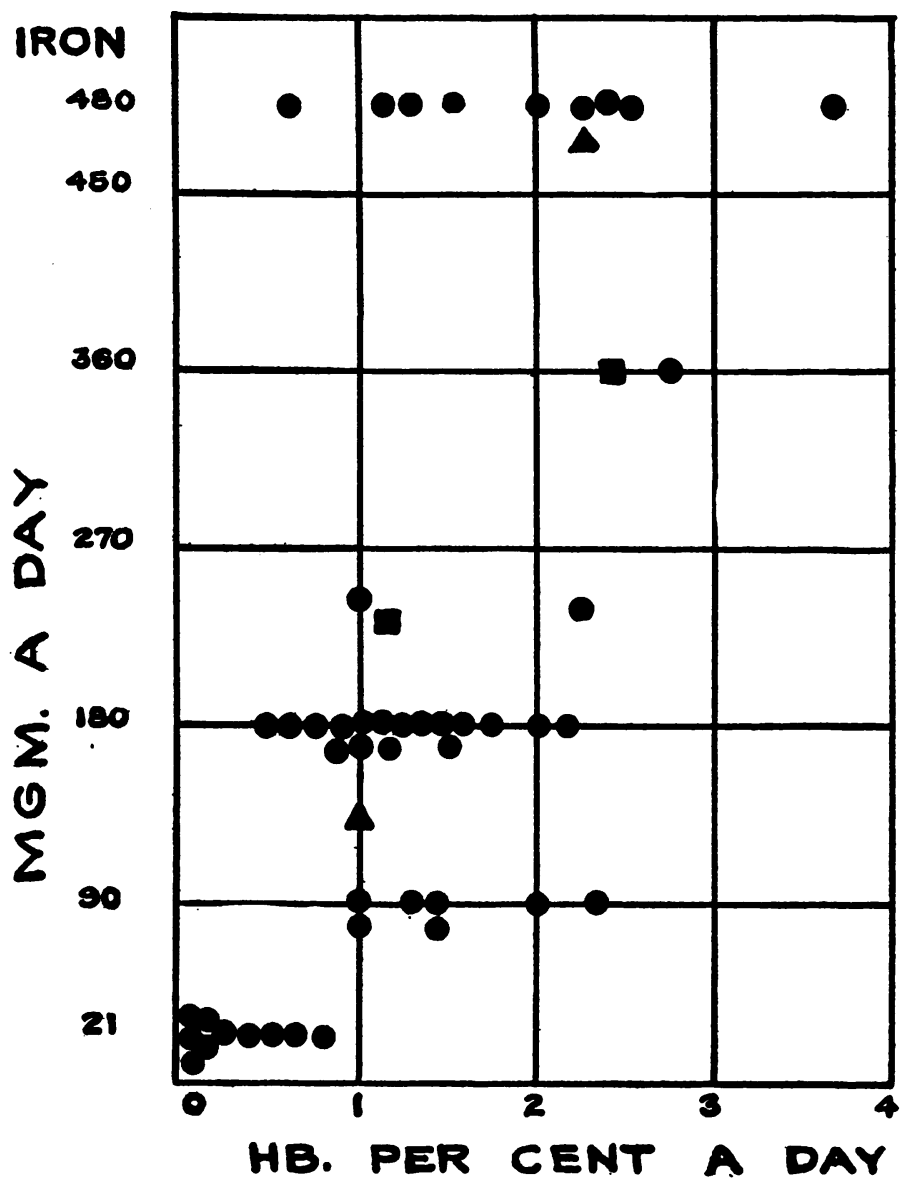

Chart 9. The Rate of Hemoglobin Regeneration a Day in 38 Patients Following Various Doses of Iron

Each dot represents a patient, and the average increase in the hemoglobin content of the blood a day after iron. The dots in the lower left hand corner represent the amount of hemoglobin put out following liver ash. The two triangles and the two squares represent the response of two different patients following different doses of iron. 
ably greater. The results of a study of seven patients who just received liver ash and then iron are recorded in table 3.

Besides calculating the average daily increases in hemoglobin following various doses of iron, we studied the response of the reticulocytes in order to determine whether large doses of iron were more effective in increasing the reticulocytes in the blood than small doses. These data are plotted in chart 10 . The percentage of reticulocytes following various amounts of iron is charted with the total number of erythrocytes before treatment. The squares represent the response following $480 \mathrm{mgm}$. of iron; the dots, $180 \mathrm{mgm}$.; the triangles, $90 \mathrm{mgm}$.; and the diamonds, $21 \mathrm{mgm}$. in the form of liver ash. It is readily seen

TABLE 3

Results of the treatment of anemia with varying doses of iron

\begin{tabular}{|c|c|c|c|c|c|c|c|c|c|c|c|}
\hline \multirow{2}{*}{ Case } & \multicolumn{2}{|c|}{ Before liver ash } & \multicolumn{2}{|c|}{$\begin{array}{c}\text { After liver ash } \\
\text { Iron content } \\
0.021 \text { gram }\end{array}$} & \multicolumn{2}{|c|}{ Before iron } & \multicolumn{2}{|c|}{ After iron } & \multirow{2}{*}{$\begin{array}{l}\text { Daily } \\
\text { dose of } \\
\text { iron }\end{array}$} & \multicolumn{2}{|c|}{ Reticulocytes } \\
\hline & $\begin{array}{l}\text { Red } \\
\text { blood } \\
\text { cells }\end{array}$ & $\begin{array}{l}\text { Hemo-- } \\
\text { globin }\end{array}$ & $\begin{array}{c}\text { Red } \\
\text { blood } \\
\text { cells }\end{array}$ & $\begin{array}{l}\text { Hemo- } \\
\text { globin }\end{array}$ & $\begin{array}{l}\text { Red } \\
\text { blood } \\
\text { cells }\end{array}$ & $\begin{array}{l}\text { Hemo- } \\
\text { globin }\end{array}$ & $\begin{array}{l}\text { Red } \\
\text { blood } \\
\text { cells }\end{array}$ & $\begin{array}{l}\text { Hemo-- } \\
\text { globin }\end{array}$ & & $\begin{array}{c}\text { Follow- } \\
\text { ing liver } \\
\text { ash }\end{array}$ & $\begin{array}{l}\text { Follow- } \\
\text { ing iron }\end{array}$ \\
\hline & millions & per cent & millions & per cent & millions & per cent & millions & per cent & grams & per cent & per cent \\
\hline 15 & 3.75 & 42 & 4.0 & 50 & 4.0 & 50 & \begin{tabular}{|l|}
5.25 \\
\end{tabular} & 90 & 0.48 & 4.2 & 9 \\
\hline 16 & 3.50 & 40 & 4.0 & 45 & 4.0 & 45 & 5.25 & 90 & 0.48 & 1.8 & 5 \\
\hline 17 & 3.0 & 52 & 4.25 & 65 & 4.25 & 65 & 5.0 & 90 & 0.36 & 1.0 & 7 \\
\hline 18 & 2.11 & 37 & 2.44 & 38 & 2.44 & 38 & 3.5 & 70 & 0.48 & 1.2 & 12 \\
\hline 20 & 2.57 & 34 & 2.50 & 33 & 2.50 & 33 & 5.0 & 90 & 0.36 & 1.0 & 7 \\
\hline 21 & 2.02 & 43 & 1.92 & 35 & 1.92 & 35 & 4.5 & 88 & 0.18 & 3.4 & 9 \\
\hline 23 & 3.33 & 52 & 3.28 & 47 & 3.28 & 47 & 4.5 & 85 & 0.48 & 2.6 & 3.4 \\
\hline
\end{tabular}

that as a general rule the lower the red blood cell count at the beginning of treatment, the greater was the increase in reticulocytes. However, this was only true of patients in whom the dose of iron was large enough to produce a positive effect. For example, the response following iron given in doses of $21 \mathrm{mgm}$. (diamonds) was never very conspicuous, but when larger doses were given to the same patients, an increase in the reticulocytes was evident. (See table 3.)

From these observations it would seem justifiable to conclude that when anemias respond to iron therapy the dosage is of importance, and large doses are relatively more effective than small ones. This has been emphasized previously by Whipple and Robscheit-Robbins 

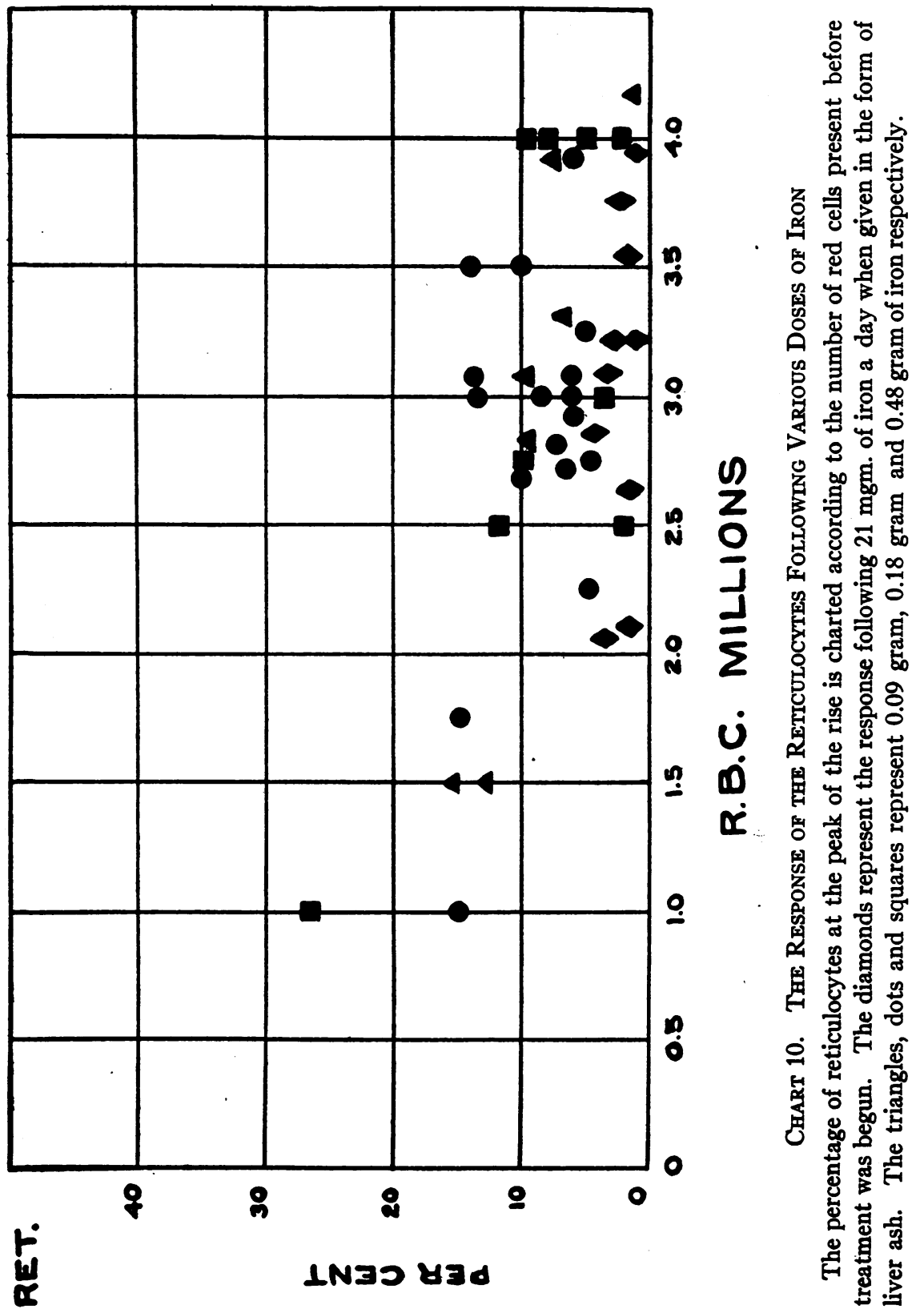
and Mettier and Minot. It would appear, however, that an increase in hemoglobin regeneration may be observed in some cases following $90 \mathrm{mgm}$. of iron daily. In others larger doses seem necessary.

It remains to discuss why iron is effective in some of the human anemias and not in others. We have pointed out the necessity of adequate amounts of iron and Mettier and Minot (24) have suggested that the reaction of the gastric secretion may be of considerable importance in determining its effectiveness. In other words, it appears that the dosage must be adequate and the conditions for its absorption favorable. There is another possibility which must be considered, namely, the value of copper in increasing the potency of iron. It has been shown that copper is potent in increasing the hemoglobin content of rats with anemia resulting from a milk diet supplemented with iron. Its value, however, as a supplement to iron in the various human anemias, remains unclear. Mills (25) has reported favorable results in some patients with a hypochromic anemia following iron and copper, and believes that copper is necessary for the maximum iron effect in this form of anemia. Moreover, he attributes the striking results obtained in some of these anemias following liver and iron to the copper content of the liver. Whether copper is necessary for hemoglobin production in other forms of anemia requires further investigation.

It would appear from these observations that the iron effect is only one factor necessary for hemoglobin regeneration, and this had been designated as the salt effect by Whipple and Robscheit-Robbins (23). In some cases, when iron is lacking, recovery will not take place until the iron is provided; in other instances, when it is available and other substances necessary for hemoglobin regeneration are lacking, recovery will not occur until they have been supplied. The exact nature of these various factors require further study.

Response of reticulocytes following various forms of treatment. When a patient with pernicious anemia recovers following liver or liver extract there is an increase in the reticulocytes; the number appearing in the circulatory blood depends upon the amount of liver or liver extract given and the number of erythrocytes present at the beginning of treatment (26). That is to say, the lower the erythrocyte count before treatment is begun and the larger the amount of liver or liver extract given, the greater the number of reticulocytes in the peripheral blood at the peak of the rise. 


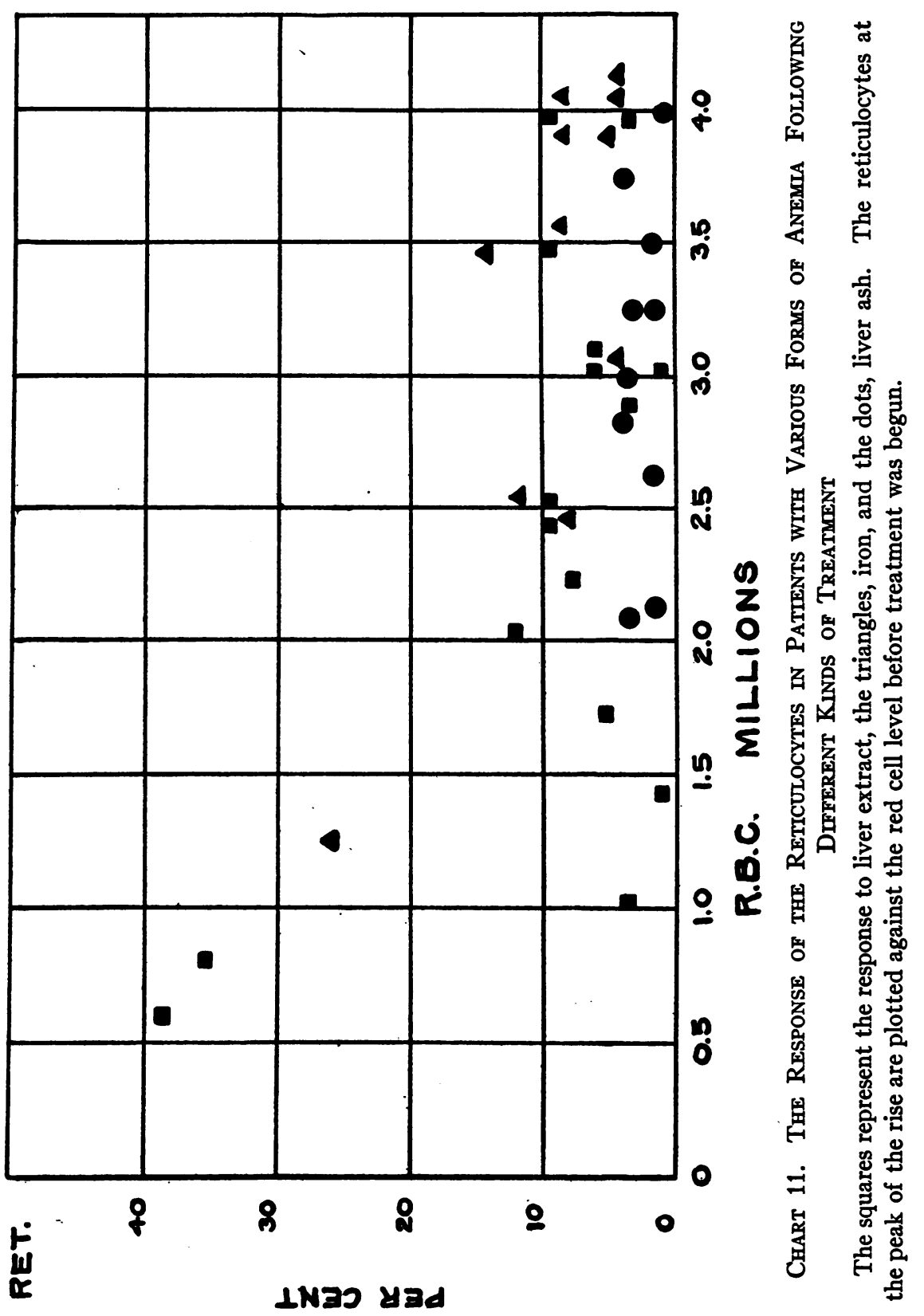


We (27) found in a study of the response of the reticulocytes following the treatment of various forms of "secondary" anemia, that the number of reticulocytes appearing in the blood depended upon the severity and cause of the anemia and the kind of treatment. In studying the response of the reticulocytes in these patients we have made chart 11. The triangles represent the reticulocyte response to iron; the squares, the response to liver extract; and the dots, that following liver ash. The most conspicuous results followed liver extract and iron, whereas, liver ash produced only slight changes. However, one may say that whenever a patient responded to either liver extract or iron, the lower the red blood cell count, the higher were the reticulocytes at the peak of the rise. The reason for the slight response of the reticulocytes following liver ash was probably due to the small amount of iron which was present.

\section{SUMMARY AND CONCLUSIONS}

We have reported the results of a study of the effect of feeding liver extract, liver ash, and iron to patients with various forms of anemia and the following facts were evident.

1. Liver extract was of demonstrable value in increasing the regeneration of hemoglobin in some of the obscure nutritional anemias of childhood, in some of the anemias associated with dysentery, hookworm infestation, and pregnancy. In some cases its effect could be enhanced by iron.

2. Liver ash, when given in amounts which were equivalent to 300 grams of whole liver, was of little demonstrable value in increasing hemoglobin regeneration. In some cases there was a slight increase in the reticulocytes, hemoglobin, and erythrocytes, but the results were never as conspicuous as those obtained with liver extract or large doses of iron.

3. Iron was effective in the treatment of various forms of anemia. Large doses were more effective than small ones. In many instances the effect of iron exceeded both liver, liver extract, or liver ash, and in some cases a favorable response did not occur until iron was added.

4. When recovery from the anemias followed either liver extract or iron there was an increase in the reticulocytes of the circulating blood. The lower the erythrocyte count before treatment, the higher were the reticulocytes at the peak of the rise. 


\section{BIBLIOGRAPHY}

1. Minot, G. R., Cohn, E. J. and Murphy, W. P., and Lawson, H. A., Am. J. Med. Sci., 1928, cluxv, 599. Treatment of Pernicious Anemia with Liver Extract: Effects upon the Production of Immature and Mature Red Blood Cells.

2. Bloomfield, A. L., and Wykoff, H. A., Am. J. Med. Sci., 1929, clxxvii, 209. The Treatment of Sprue with Liver Extract (343).

3. Ashford, B. K., J. Am. Med. Assoc., 1928, xci, 242. An Evaluation of Liver Extract in the Treatment of the Anemias of Sprue; Preliminary Note.

4. Richardson, W., and Klumpp, T. G., New Eng. J. Med., 1928, cxcix, 215. Sprue: Report of a Case Treated with the Authorized Liver Extract Effective in Pernicious Anemia.

5. Porter, William B., and Rucker, J. E., Am. J. Med. Sci., 1930, clxxix, 310. The Treatment of Nontropical Sprue with Liver Extract.

6. Richter, Oscar, Maurer, S. and Eyl, M., J. Am. Med. Assoc., 1928, xci, 1462. Treatment of Severe Dibothriocephalus Latus Anemia, with a High Caloric Diet, Rich in Liver Extract and Vitamins.

7. Faber, H. K., Am. J. Dis. Child., 1928, xxxvi, 1121. The Value of Liver Extract (343) in Identifying and in Treating Certain Anemias of Infancy and Childhood; Report of a Case of Probable Primary Anemia in Infant Nine and One-half Months Old.

8. Keefer, C. S., and Yang, C. S., Nat. Med. J. of China, 1929, xv, 701. Anemia of Undernutrition. Report of Cases with Results of Treatment.

9. Little, W. D., Zerfas, L. G., and Trusler, H. M.: J. Am. Med. Assoc., 1929, xciii, 1290. Chronic Obstruction of the Small Bowel. The Result of Two Entero-enterostomies and Apparently the Cause of Pernicious Anemia.

10. Keefer, C. S., Yang, C. S., and Huang, K. K., (In press). Anemia Associated with Chronic Dysentery, Clinical Considerations, with Special Reference to Its Cause and Treatment.

11. Yang, C. S., and Keefer, C. S., Nat. Med. J. of China, 1930, xvi, 159. The Anemias of Pregnancy with Special Reference to their Cause and Treatment.

12. Peterson, R., Field, Henry, Jr., Morgan, H. S., J. Am. Med. Assoc., 1930, xciv, 839. Liver Treatment in the Pernicious Anemia of Pregnancy.

13. Minot, G. R., Murphy, W. P., and Stetson, R. P., Am. J. Med. Sci., 1928, clxxv, 581. The Response of the Reticulocytes to Liver Therapy: Particularly in Pernicious Anemia.

14. Vaughan, J., Lancet, 1928, i, 1063. Investigation of a Series of Cases of Secondary Anemia Treated with Liver or Liver Extract.

15. Robscheit-Robbins, F. S., and Whipple, G. H., J. Exp. Med., 1929, xlix, 215. Blood Regeneration in Severe Anemia. XIV. A Liver Fraction Potent in Pernicious Anemia Fed Alone and Combined with Whole Liver, Liver Ash, and Fresh Bile.

16. Hart, E. B., Steenbock, H., Waddell, J., and Elvehjem, C. A., J. Biol. Chem., 1928, lxxvii, 797. Iron in Nutrition: VII. Copper as a Supplement to Iron for Hemoglobin Building in the Rat. 
17. Robscheit-Robbins, F. S., Elden, C. A., Sperry, W. M., and Whipple, G. H., J. Biol. Chem., lxxix, 563. Blood Regeneration in Severe Anemia. XII. Potent Influence of Inorganic Ash of Apricots, Liver, Kidney, and Pineapple.

18. Elden, C. A., and McCann, W. S., Proc. Soc. Exp. Biol. and Med., 1928, xxv, 746. Effect of Ash of Liver on Blood Regeneration in Pernicious Anemia.

19. Whipple, G. H., Robscheit-Robbins, F. S., Elden, C. A., and Sperry, W. M., Proc. Soc. Exp. Biol. and Med., 1928, xxv, 748. Blood Regeneration in Severe Experimental Anemia. Influence of Inorganic Elements.

20. Sperry, W. M., Elden, C. A., Robscheit-Robbins, F. S., and Whipple, G. H., J. Biol. Chem., 1929, lxxxi, 251. Blood Regeneration in Severe Anemia. XV. Liver Fractions and Potent Factors.

21. Keefer, C. S., and Yang, C. S., J. Am. Med. Assoc., 1929, xciii, 575. The Value of Liver and Iron in the Treatment of Secondary Anemia.

22. Robscheit-Robbins, F. S., Physiol. Rev., 1929, ix, 666. The Regeneration of Hemoglobin and Erythrocytes.

23. Whipple, C. H., and Robscheit-Robbins, F. S., Am. J. Physiol., 1930, xcii, 362. Blood Regeneration in Severe Anemia. XVI. Optimum Iron Therapy and Salt Effect.

24. Mettier, S. R., and Minot, G. R., J. Clin. Invest., 1929, vii, 510. The Effect of Iron on Blood Formation as Influenced by Changing the Acidity of the Gastric Contents in Certain Cases of Anemia.

25. Mills, E. S., Can. Med. Assoc. J., 1930, xxii, 175. The Treatment of Idiopathic (Hypochromic) Anemia with Iron and Copper.

26. Minot, G. R., Murphy, W. P., and Stetson, R. P., See 13.

27. Yang, C. S., and Keefer, C. S., jArch. Int. Med., 1930, xlv, 456. The Response of the Reticulocytes in Secondary Anemia Following Various Forms of Treatment. 